\title{
Speech Ability of Grade 10 Students
}

\author{
Marissa Regalado-Villamon \\ Faculty of the Graduate School, \\ Surigao Del Sur State University, Tandag, Philippines
}

\begin{abstract}
This paper attempts to assess the speech ability of the grade 10 students in Jose Sanvictores Sr. National School in Cagwait, Surigao del Sur. It uses random sampling which identifies 70 respondents. This study used descriptive - correlational method in order to determine the level of speech ability of Grade 10 students.
\end{abstract}

The study dealt with the following objectives: to determine the profile of the respondents in terms of gender, language facility, parent's educational attainment, media preference, communication practice, use of English and medialpreference; to identify the level of oral language proficiency as to grammar, vocabulary, pronunciation and fluency; and to assess the significant relationship between the profile of the participants and the level of speech ability.

\section{THE PROBLEM AND ITS SETTING}

Speaking is described as the ability to express oneself in the situation, or the activity to report acts, or situation in precise words or the ability to converse or to express a sequence of ideas fluently ( Ladouse, 1991). Furthermore, Tarigan (1990) said that "Berbicara adalah cara untuk berkomunikasi yang berpengaruh hidup kita sehari-hari”. It means that speaking as the way of communication influences our individual life strongly.

Speaking therefore is the ability to speak a language in real-life settings, outside of the classroom. It describes how well a speaker of the target language can speak a language in the real world, regardless of the textbook, grades, or class goals. It is the foundation for student learning. It is essential for literacy learning, and successful use of language is critical for students' wellbeing.
Since the onset of the communicative era, it was the ultimate goal of language training and its proper development has become the focus of attention of teachers and learners. Thus, this paper attempt to assess the level of speech ability of the participants regarding of grammar, vocabulary, pronunciation and fluency. Further, significantly correlate the relationship between the profile of the learners and their level of speech ability.

In foreign and second language teaching and learning, speaking is an essential skill since it is the most basic in communication and it is the most difficult skill, (Oradee, 2012).According to Looh (2009), to be proficient in the language is recognized as critical for functioning in an English language context, both by teachers and by learners.

Additional supports come from an article by Chandra as cited by Soniel (2010), one of the language skills that must be mastered by any foreign language learner is the ability to speak or communicate in the target language fluently. Same through is the insight shared by Aquino as cited by Salvaleon (2009) when she suggests that the mastery of the English language is an essential tool to be successful academically and in the competitive business world students will someday face. How someone speaks determines his success in his profession and his interpersonal relationship. She puts forward that, as a learner, exploration of the speaking ability is necessary to participate fully and productively in the society.

Nowadays, Speaking is important since oral communication involves speech where learners expect to interact verbally with other people. Speaking is the most undeveloped part of the language learning and one of the most important elements of communication that needs careful consideration by EFL teachers 
(Tokoz-Goktepe, 2014). In learning a foreign language, globalization is one factor to consider in order to speak fluently. Around the world, most companies look for individuals who communicate with other people using the language. Consequently, most English language learners regard speaking as an important factor that needs to be mastered to become fluent and to achieve success in spoken communication (Barakat \& Mohammadi , 2014). Speaking seems to be the most important skill since language exists for the purpose of communication. Without speech, we cannot communicate with others. Thus we are supposed to speak correctly and effectively in-order to communicate well with others. It is the teacher's job and responsibility to help students develop their speaking skill by selecting the effective classroom assessment activities and strategies that make learners more comfortable to speak and overcome their fear and hesitation (Moradi \& Talebi, 2014).

This assessment provides valuable data in determining the errors of grade 10 students' speech ability. It will also help the teachers form instructional decisions necessarily in language learning. Understanding students' speech ability helps teachers to guide instruction and adjust their own language accordingly. Knowing students level of speech ability also influences the teachers' selection of appropriate reading texts that are more in alignment with students 'speaking level. On the other hand, the matter is important because if the students' second language proficiency is inadequate, the teaching of content in the second language will be impaired.

\section{Theoretical Framework}

This paper anchored to Krashen's Second Language Theory. This theory has proven to be both influential and controversial. The significance of the theory for speaking lies in the theory that learned competence and acquired competence develop in very different ways. According to him, language learning occurs through formal study of rules, patterns, and conventions and as individual learns, he applies what he learned. However, in language acquisition, learning comes in a different way. Krashen believes, through "comprehensible input." Comprehensible input means that second-language students develops language competence by exposure to language that is both understandable and meaningful to them. By concentrating on meaning, they subconsciously grasp form. The most valuable input for acquisition is language that goes just a step beyond the structures which second-language students have already accumulated (or, in Krashen's terminology, i +1 , where i represents language at the students' current level of competence). No matter how appropriate the input, however, the acquisition will not occur if a student's "affective filter" or collection of emotional responses that impede comprehension of meaning is raised. Importantly, Krashen insists that learning does not turn into acquisition except in a certain convoluted way. This occur only when second-language students successfully monitor their language production and provide their own grammatically correct comprehensible input. This self-produced input then becomes part of the total necessary for acquisition to take place

Since Krashen's research indicates that competence acquired is so much more accessible and reliable than learned competence, teachers should help students exploit their acquired competence in whatever ways possible.

According to Chomsky in his Language Acquisition Theory, competence is the ideal language system that enables speakers to produce and understand an infinite number of sentences in their language, and to distinguish grammatical sentences from ungrammatical sentences. It was unaffected by "grammatically irrelevant conditions" such as speech errors. In Chomsky's view, competence is studied independently of language use, which falls under "performance," for example through introspection and grammaticality judgments by native speakers.Another theory that supports this study is the Speech Act Theory of J.L. Austin, a British philosopher of languages. He introduces this theory in 1975 in his well-known book of "How to do things with words". This explanation in the field of philosophy of languages is used. Austin is the one who came up with the findings that people not only uses that language to assert things but also to do things. Individuals who followed him went to greater depths based on this point. He taught that the meaning of language depends on its actual use. Language, as used in ordinary life, is a game because it consists of rules. The speech act is the primary unit language use to express meaning, an utterance that expresses an intention.

Previously it was conceived that the very basic unit of communication is words, Symbols, sentences or some 
token of all of these, but it was speech act theory which suggested that production or issuances if words, symbols are the basic units of communication. This emergence happens during the process of performance of speech act. The meaning of these basic units as the building blocks of mutual understanding between the people intend to communicate gave a consideration. The theory emphasizes that the utterances have a different or specific meaning to its user and listener other than its meaning according to the language.

The philosophy further identifies that there are two kinds of utterances; they are constative and performative utterances. A constative utterance is something that describes or denotes the situation, in relation with the fact of true or false and the performative utterances is something that does describes anything at all. The articulation in the sentences or in the part of sentences as having a meaning of its own is also considered. The feelings, attitudes, emotions and thoughts of the person performing linguistic act are much of a primary unit here.

Aside from listening, reading and writing, speaking is one of the four-macro skills that is important for effective communication. As it was noted at the beginning of this work, the main objective of learning any foreign language is to be able to speak and communicate in that language. So speaking is important since it provides learners with the opportunity to hold a well carried conversation as well as manage interaction.

As proverb says, "practice makes perfect," therefore, students must practice speaking the English language always so that they will be able to speak fluently and accurately. To speak English correctly, we have to know the important elements of speaking. The elements of speaking are grammar, vocabulary, pronunciation, and fluency.

Grammar ability includes knowledge of, sound-letter relationships, and the rules of word and sentence formation. This category of communicative competence was traditionally associated with language learning.

Vocabulary refers to the appropriate diction used in communication. Having insufficient amount of vocabulary hinders one to communicate effectively or express ideas. It also prevents an individual improve in his second language learning. Therefore, in language learning situations, teachers who have wide vocabulary learnings can help students gain a great success in their vocabulary learning. Without enough grammar, one conveys very little only and without sufficient vocabulary, nothing is conveyed.

Pronunciation, on the other hand is the way for students' to produce clearer language when they speak. It deals with how an individual pronounce and enunciate words properly. It also refers to whether the right word is properly stressed.

The last component, fluency can be defined as the ability to speak fluently and accurately. Fluency in speaking means speaking with no signs of jitters and there are no halting speech. It means that the words spoken do not devolved into broken strings. There is speed in talking and there are only a small number of pauses and "um" or "ers." These signs indicate that the speaker does not have to spend a lot of time searching for the language items needed to express the message (Brown. 1997: 4).

\section{Conceptual Framework}

The study claimed that indicators such as their language facility, communication practice, parents' educational attainment, use of English at home and media preference, affect the level of students' speaking ability.

Language facility exposes the students towards better oral communication. The daily undertakings in the classroom helps enhance learning. In addition, the various oral communication that takes place in the classroom gives a relevant training.

Likewise, communication practice measures whether the students are exposed to a wide range of academic vocabulary and linguistic structures from the very early grades without having to go through the process of learning them piece by piece. Communication practice, on the other hand, is the powerful predictors of the use of speech ability strategies among the learners. Consequently, parents' level of education is a predictor of children's academic achievement. It is part of a larger constellation of psychological and sociological variables influencing children's school outcomes. Higher levels of education may be access to resources, such as income, time, energy, and community contacts, that allow for greater parental involvement in a child's education. Thus, students 
whose parents have higher levels of education may have an enhanced regard for learning, more ability beliefs, a stronger work orientation, and they may use more useful learning strategies than children of parents with lower levels of education.

Moreover, use of English at home allows the speaker to master the target language essentially. Students who use English at home on a daily basis need to be able to use

English for a variety of purposes. They have an easier time learning English when they have a strong foundation of the language. These influences will help students to stay connected, be informed and allow them the opportunity to construct ideas and opinions about the world around them.

Furthermore, media preference plays a motivating and enhancing learning in schools of the $21^{\text {st }}$ century. Media and technology can play an important role to improve instruction especially in learning the English language. It offers an easier and even faster environment to access and retrieve information.

On the other hand, Speaking as one of the skills in English learning is also affected by several components. These components influence the speech ability of the learners. How well an individual speaks is greatly influenced by the grammar, vocabulary, pronunciation and fluency. Grammar student's ability to manipulate structure and to distinguish appropriate grammatical form in appropriate one. The utility of grammar is also to learn the correct way to gain expertise in a language in oral and written form. Vocabulary is the stock of words used by the learners. Insufficient vocabulary hinders a student in expressing his own self. While pronunciation phonological process that refers to the components of a grammar made up of the elements, principles that determine how sounds vary, and pattern in a language. Lastly. fluency equally determines the speech ability because a fluent speaker need not to spend a lot of time searching for the language items needed to express his message.

The schematic diagram shows the sequential workflow of the study. The first box presents the independent variables. These variables include language facility, communication practice, educational attainment of the parents, and use of English and media preferences. The second box serves as the dependent variables of the study, which refer to the level of Grade 10 students' speech ability regarding the four competencies: grammar, vocabulary, pronunciation and fluency.

The third box reflects the output of the study, wherein an intervention program is proposed based on the findings of the study.

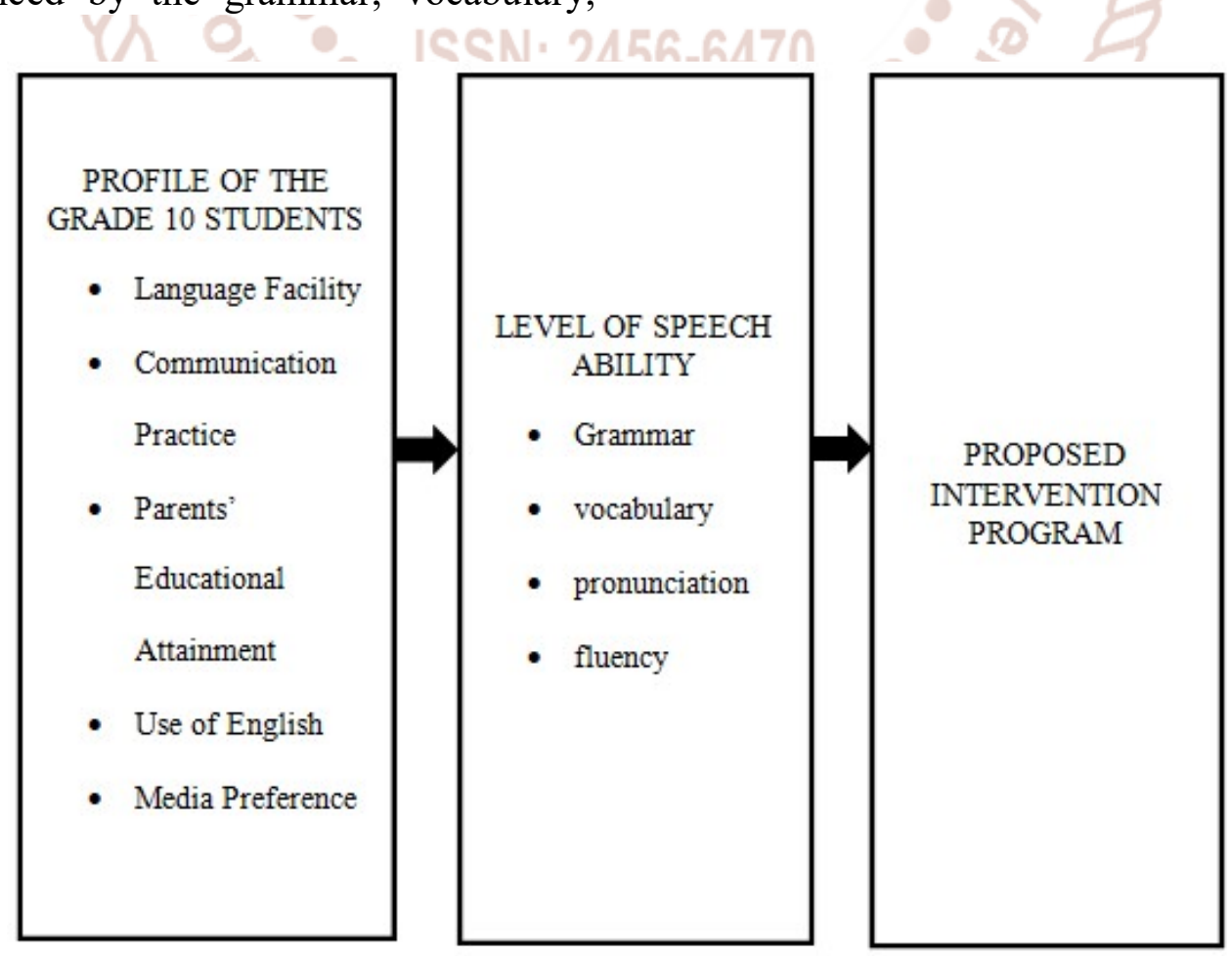

Figure 1. Schematic Diagram of the Study 


\section{Statement of the Problem}

This study aimed to determine the speech ability of the grade 10 students of the Jose Sanvictores Sr.National High School.

Specifically, the following problems answer the following:

1. What is the profile of the participants regarding the following variables:
1.1. Gender;
1.2. Language Facility;
1.3. Communication Practice;
1.4. Parents' Educational Attainment
1.5. Use of English at Home; and
1.6. Media Preference?

2. What is the level of speech ability of the participants regarding the following variables
2.1. Grammar;
2.2. Vocabulary;
2.3. Pronunciation;
2.4. Fluency?

3. Is there a significant relationship between their profile of the participants and their level of speech ability?

4. What intervention can be designed based on the findings of the study?

\section{Hypothesis}

Ho1: There is a significant relationship between the profile of the participants and their level of speech ability.

\section{Significance of the Study}

The findings of this study endeavors to supply data that the researcher believes will be valuable to the following:

The School Administrators/School Officials. The outcome of the research will be helpful and advantageous to the school principals/school heads, English chairpersons and other school officials in generating alertness of the diverse kinds of students with varying degrees. Furthermore, results of this research will be directed in adopting corrective procedures for the progress of instructional material like in English to manufacture graduates who can be better and useful citizens of the country.
The Grade 10 teachers. Knowing the product of the study, they can create helpful steps to achieve further the speech ability of their students. It can also lead to the discovery of ways and means to develop the language and instruction and learning in the classroom, proper construction of the lesson plan and instructional material appropriate to the needs of the learners.

Grade 10 Students. After being responsive of their speaking ability in English communication, the result and findings of this study will prompt them to the aspiration for excellence-the desire to be very skilled in speaking for only those who have mastered of what is required in the language will find greater satisfaction and success.

Department of Education. This will also be significant to the Department of Education and will help understand the reasons why young learners in grade 1 basic education schools find it difficult to speak in English.

\section{Scope and Delimitation}

This study focused on the speech ability of Grade 10 students regarding grammar, vocabulary, pronunciation and fluency. The study will cover the Grade 10 students of Jose Sanvictores Sr.National School, Cagwait Surigao del Sur for the Academic Year 2016-2017.

\section{Definition of Terms}

The following terms will be defined for a better understanding of the study.

Speech is an interactive process of constructing meaning that involves producing and receiving and processing information. Speech depends on the context or the situation, context, includes the physical environment, the purposes for speaking is more often spontaneous, open-ended, and evolving. Speech requires learners to not only know how to produce specific points of language such as grammar, pronunciation, or vocabulary but also that they understand when, where, why and in what ways to utter a language.

Communication Practice refers to the different ways to communicate through reading, writing, speaking, listening, visual means, etc. It includes all means of ensuring that voice is heard by different people, in a 
different language, at different levels, in different context and at different times.

Foreign Language is a language indigenous to another country and not spoken in the native country of the person.

Speaking Skills. Speaking skills is defined as communicating activities. In this study refers to the activities using the English language and the language areas.

Grammar refers to the classes of words, their inflections, and functions and relations in the sentence.

Vocabulary is a set of familiar words within a person's language. It is usually developed with age, serves as a useful and fundamental tool for communication and acquiring knowledge.

Fluency is a speech-language pathology term that means the smoothness or flow with which sounds, syllables, words, and phrases joined when speaking quickly. It is the ability to talk at length with few pauses. A speaker can express his or her idea in a coherent way. Likewise, she deals with lexical and syntactic items at a fast speed.

Pronunciation is the way a word or a language is spoken, or the manner in which someone utters a word. If one is said to have "correct pronunciation," then it refers to both within a particular dialect.

Speech Act is linguistics, and the philosophy of language is an utterance. Alternatively, an utterance serves a function in communication.

\section{RESEARCH METHODOLOGY}

This chapter discusses the methodology of the study. It describes the research design, research instrument, research environment, research respondents, data gathering procedure and scoring and statistical tools used in treating the data.

\section{Research Design}

This study employed descriptive evaluative and correlation research design to assess the status of the Speech Ability of Grade 10 students and to establish the significant relationship between the respondents profile and their level of speech ability. Through these designs, the researcher studies and describes questionnaires and does not interfere with the situation, condition and variables and does not tamper with or controls them.

In particular, the study used launching of questionnaires to establish the profile of the respondents in terms of Gender; Language Facility; Communication Practice; Parents' Educational Attainment Use of English at Home; and Media Preference.

\section{The Research Environment}

Jose Sanvictores Sr. National School Annex is a DepED Managed partially urban Secondary Public School located in Cagwait, Surigao Del Sur.

It teaches students in grades seventh through eleventh grade. The school has 16 instructional rooms, one two storey- 6 classrooms for Senior High School and 4 non-instructional rooms, which are all powered by a power grid. With 450 students, class size is around 69 students. All of the instructional rooms, all of them are standard rooms, meaning they meet the DepEd's guidelines for safety and usability

For the 2016-2017 school year, Jose Sanvictores Sr. National School Annex had started the Senior High School and offered tracks such as GAS and TVL ( dressmaking). This makes the school a larger school.

\section{Participants of the Study}

Jose Sanvictores National School has a total population of 450 students from grade seven to grade eleven.The population of Grade 10 is representing 20 $\%$ with respect to the total population. Seventy (70) students were taken as respondents of the study.

\begin{tabular}{|l|l|l|l|}
\hline Respondents & $\begin{array}{l}\text { Total } \\
\text { Males }\end{array}$ & $\begin{array}{l}\text { Total } \\
\text { Females }\end{array}$ & $\begin{array}{l}\text { Total } \\
\text { Number of } \\
\text { Respondents }\end{array}$ \\
\hline $\begin{array}{l}\text { Grade 10 } \\
\text { Rutherford }\end{array}$ & 18 & 16 & 34 \\
\hline $\begin{array}{l}\text { Grade 10 } 10 \\
\text { Becquerel }\end{array}$ & 19 & 17 & 36 \\
\hline Total & 37 & 33 & 70 \\
\hline
\end{tabular}

Figure 1. Distribution of Respondents 


\section{Research Instrument}

In order to gather the necessary data of the study, an instrument was used in a form of questionnaire and rubrics. The instrument composes of two (2) parts. Part I includes the profile of the respondents as to language facility, communication practice, educational attainment of the parents, use of English and media preference. Part II uses rubrics to assess the level of speech ability in terms of grammar, vocabulary, pronunciation and fluency. The adopted rubric from the study of Lasale (2014) was modified slightly so as to be able to obtain the level of students' speech ability

\section{Data Gathering Procedure}

The data gathering procedure facilitated by an approved permit from the school principal of the school respondents. Another letter was sent to the concerned teachers to assist and to stand as evaluators of the respondents' performance to oral language proficiency. After the approval, the questionnaire was administered to the participants.

The questionnaires then were retrieved and tallied ready for statistical treatment while the data, after which the researcher listens and rate according to the adopted rubrics and scale. It was then analyzed and interpreted.

The data for problem number 2 was recorded through the use of a cell phone. The respondents listened as the researcher reads a story script of ten (10) sequenced pictures. Then the respondents were instructed to retell the story while looking at the picture. The recorded voice was transcribed, analyzed and scored according to the rubric's scale.

\section{Scoring}

The respondents' oral exercise was rated according to the scale below:

\begin{tabular}{|l|l|}
\hline Scale & Adjectival Rating \\
\hline 5 & Superior \\
\hline 4 & Very Good \\
\hline 3 & Acceptable \\
\hline 2 & Marginal \\
\hline 1 & Poor \\
\hline
\end{tabular}

For clarity of the rating, the following descriptions are given to the following scales:
Superior. The student is enthusiastic; extremely active effort to communicate with a wide variety of means, non-verbal and verbal to express himself or herself. Student is never hesitant and halting, smooth and nearly effortless, approaches near-native delivery. The delivery is of complete utterances, appropriate expressions, and use of the isolated words when appropriate and conveys all information in the communication task with all relevant facts included.

Very Good. The student is interested; with concrete effort to communicate and went well beyond the task requires. The delivery is seldom halting or hesitant, fairly smooth and effortless. Further, there are very few inappropriate expressions or isolated words, incomplete statements, mostly complete utterances and the student is able to convey information in the communication task with nearly all relevant facts are included.

Acceptable. The student is alert; complete the communication task and add something not specifically called for. Delivery is occasionally halting and hesitant with a few fragmented utterances and unnatural pauses that is characterized by an occasional inappropriate expression, few isolated words with many short, some incomplete statements, and complete utterances. Moreover, student conveys information called for the communication task with relevant facts included.

Marginal. The student is lightly attentive; expressed what comes easily, but appears unwillingly with any special effort. Delivery is often halting and hesitant, few unnatural pauses and fragmented utterances characterized by few inappropriate expressions, incomplete statements, and isolated words which are short, and complete utterances. Further, the student is able to convey information in the communication task with large relevant facts omitted.

Poor. The student is listless; appears no to care on message properly conveyed. The delivery is constantly halting and hesitant with large number of fragmented utterances and unnatural pauses characterized by constant flow of inappropriate expressions, incomplete statements, and isolated words of few short complete utterances. Likewise, the student conveys very little information called for the communication task and relevant facts are omitted. 


\section{Statistical Treatment}

After the instruments were tallied and ready for statistical treatment, the researcher will then consult the statistician and subject the data for statistical treatment.

Part I on the demographic profile of the participants, frequency counting and ranking will be used.

Part II on the level of oral language proficiency, Weighted Mean was employed.

Part III on the relationship of the independent and dependent variables, the Pearson R Product Moment of Correlation test was used.

\section{PRESENTATION, ANALYSIS INTERPRETATION OF DATA}

AND

This chapter presents, analyzes and interprets the gathered data of the study. The data are arranged in tabular from following the order of the problems presented in chapter 1 .

\section{The Profile of the Participants}

Table 2

Participants' Profile as to Gender

\begin{tabular}{|l|l|l|}
\hline \multicolumn{1}{|c|}{ Gender } & \multicolumn{1}{c|}{ Frequency } & \multicolumn{1}{c|}{ Percentage } \\
\hline Male & 37 & $52.86 \%$ \\
\hline Female & 33 & $47.14 \%$ \\
\hline Total & $\mathbf{7 0}$ & $\mathbf{1 0 0 \%}$ \\
\hline
\end{tabular}

The table presents the profile of the respondents in terms of gender. Based on the figure, the dominated gender among the respondents is male. Males surpass females' enrolment of the school respondent. The male-female ratio in enrolment has been steadily moved in favor of the females starting this school year. Total enrollment show that females outnumbered males for the first time.
Table 3

Participants' Language Facility

\begin{tabular}{|l|l|l|}
\hline \multicolumn{1}{|c|}{ Indicators } & \multicolumn{1}{|c|}{$\begin{array}{c}\text { Weighted } \\
\text { Mean }\end{array}$} & \multicolumn{1}{|c|}{$\begin{array}{c}\text { Adjectival } \\
\text { Rating }\end{array}$} \\
\hline $\begin{array}{l}\text { 1. I Talk to teachers in } \\
\text { English }\end{array}$ & 3.09 & Often \\
\hline $\begin{array}{l}\text { 2. I Express opinion in } \\
\text { English }\end{array}$ & 2.37 & Sometimes \\
\hline $\begin{array}{l}\text { 3. I Explain the } \\
\text { response in English }\end{array}$ & 2.20 & Sometimes \\
\hline $\begin{array}{l}\text { 4.I Make a request in } \\
\text { English }\end{array}$ & 2.59 & Sometimes \\
\hline $\begin{array}{l}\text { 5. I Give long answer } \\
\text { to teacher's question } \\
\text { in English }\end{array}$ & 2.41 & Sometimes \\
\hline $\begin{array}{l}\text { Overall Weighted } \\
\text { Mean }\end{array}$ & $\mathbf{2 . 6 1}$ & Sometimes \\
\hline
\end{tabular}

The above tables appears that the participants often use English in talking to teachers but sometimes express their opinion, explain their response, make request and give long answer to teachers' question in English as shown in the adjectival rating with the general mean of 2.61 .

According to Lubin (2001), language facility serves as an opportunity for the students towards wider exposure in various oral communications setting as well as a challenge to realize the need for more comprehensible communication of ideas. Talking to teachers in English warms the student up, and it gives them the sense that English can be used for communication. The more students talk, the more likely they are to improve.

Nevertheless, when language facility sometimes takes place, there is a tendency that student could hardly speak a word, never could speak in sentences or tell anything much. These findings are supported by Brindey (2010) who found out that a child with poor language facility is unable to form sentences and fluently put ideas into words. 
International Journal of Trend in Scientific Research and Development (IJTSRD) ISSN: 2456-6470

Table 4

Respondents' Communication Practice

\begin{tabular}{|c|c|c|}
\hline Indicators & $\begin{array}{l}\text { Weighted } \\
\text { Mean }\end{array}$ & $\begin{array}{l}\text { Adjectival } \\
\text { Rating }\end{array}$ \\
\hline $\begin{array}{l}\text { 1.I pronounce English } \\
\text { words clearly }\end{array}$ & 2.61 & Sometimes \\
\hline $\begin{array}{l}\text { 2. I use correct grammar } \\
\text { when speaking and writing }\end{array}$ & 2.50 & Sometimes \\
\hline $\begin{array}{l}\text { 3. I use appropriate words } \\
\text { in oral and written }\end{array}$ & 2.51 & Sometimes \\
\hline $\begin{array}{l}\text { 4. I show adequate stock of } \\
\text { vocabulary when speaking } \\
\text { and writing }\end{array}$ & 2.11 & Sometimes \\
\hline $\begin{array}{lr}5 . \quad \text { I give } & \text { correct } \\
\text { generalization } & \text { or } \\
\text { conclusion, } & \text { words } \\
\text { structures and utterances to } \\
\text { achieve a unified } & \text { spoken } \\
\text { language } & \end{array}$ & 2.31 & times \\
\hline Overall Weighted Mean & 2.41 & Sometimes \\
\hline
\end{tabular}

The above table discloses that respondents sometimes pronounce English words correctlytand show adequate stock of vocabulary when speaking. Overall, the respondents' communication practice weighted 2.41 which fall under the adjectival rating of sometimes. It only means that students have poor communication practice.

In the study of Hassan (2012) on the beliefs and practices in the teaching of oral language in ESL classroom, the result suggest that both teachers and students perceive oral language proficiency as an important language skill that one of the contributing factors why students are unable to secure job when they graduate because of poor communication practice. This is supported by a survey conducted by the Malaysian Government where they found out that poor communication practice results to poor oral communication skills in English (Malaysia Today, 2005). A students' ability to communicate effectively greatly affect their performance in school as well.
Table 5

Respondents' Use of English

\begin{tabular}{|l|l|l|}
\hline \multicolumn{1}{|c|}{ Indicators } & \multicolumn{1}{|l|}{$\begin{array}{l}\text { Weighted } \\
\text { Mean }\end{array}$} & $\begin{array}{c}\text { Adjectival } \\
\text { Rating }\end{array}$ \\
\hline $\begin{array}{l}\text { 1. I communicate with my } \\
\text { parents in English }\end{array}$ & 2.50 & Sometimes \\
\hline $\begin{array}{l}\text { 2. I communicate with my } \\
\text { siblings in English }\end{array}$ & 2.76 & Sometimes \\
\hline $\begin{array}{l}\text { 3. I communicate with } \\
\text { other family members in } \\
\text { English }\end{array}$ & 2.51 & Sometimes \\
\hline $\begin{array}{l}\text { 4. I communicate with } \\
\text { friends in English }\end{array}$ & 2.74 & Sometimes \\
\hline $\begin{array}{l}\text { 5. I converse over the } \\
\text { phone in English }\end{array}$ & 2.57 & Sometimes \\
\hline Overall Weighted Mean & $\mathbf{2 . 6 2}$ & Sometimes \\
\hline
\end{tabular}

The table presents the respondents' use of English. It can be gleaned in the table that respondents' use of English has an overall weighted mean of 2.62 under the adjectival rating of sometimes.

It is apparent to note that the dominance of mother tongue is regarded as one of the causes why the use of English language is sometimes used. The situation contributes immensely in poor learning of English language. According to Mohammed (2002), students often use native language or mother tongue in all their interactions and English is only used within the four walls of the classroom and it ends there.

It is supported by a study investigated the causes of poor performance in English language among secondary school students in Dutse metropolis of Jigawa state by Mosha (2014). The findings indicates that students' infrequent use of English language at school and home, large class size, teachers' responsibilities, poor conducive teaching and learning environment in the classrooms, limited home support environment and poverty were contributing factors for English poor. 
International Journal of Trend in Scientific Research and Development (IJTSRD) ISSN: 2456-6470

Table 6

Parents of the Respondents' Educational Attainment

\begin{tabular}{|l|l|l|l|l|l|l|}
\hline Indicator & $\begin{array}{l}\text { Father } \\
\text { (Frequency) }\end{array}$ & $\%$ & Rank & $\begin{array}{l}\text { Mother } \\
\text { (Frequency) }\end{array}$ & $\%$ & Rank \\
\hline Elementary Graduate & 37 & 52.86 & 1 & 27 & 38.57 & 1 \\
\hline High School Graduate & 28 & 40.00 & 2 & 33 & 47.14 & 2 \\
\hline $\begin{array}{l}\text { Technical/Vocational } \\
\text { Graduate }\end{array}$ & 0 & 0 & & & 0 & \\
\hline College Graduate & 4 & 5.71 & 3 & 10 & 14.29 & 3 \\
\hline Masteral Graduate & 0 & 0 & 0 & 0 & 0 & 0 \\
\hline
\end{tabular}

The above table reflects the educational attainment of the respondents' parents. It shows that $91.43 \%$ of parents are elementary graduate and $87.14 \%$ of parents are high school graduates. Parents' educational qualification can greatly affect the academic success and educational experience of the students specifically in learning the English language. There has been a growing body of research evidence suggesting that there are important benefits to be gained by students' parents provide support, encouragement and direct instruction in the home, as well as maintain good communications with the school -- activities which are known as "parent involvement". On the other hand, children from families with low educational attainment were at a greater risk of poor literacy, Norton (2015).

\section{Table 7}

\section{Media Preferences of the Respondents}

\begin{tabular}{|l|l|l|}
\hline Indicators & Weighted & Rank \\
\hline $\begin{array}{l}\text { Filipino } \\
\text { Programs in TV }\end{array}$ & 4.41 & 1 \\
\hline $\begin{array}{l}\text { Filipino in } \\
\text { Programs } \\
\text { Radio }\end{array}$ & 4.40 & 2 \\
\hline $\begin{array}{l}\text { English Programs } \\
\text { in TV }\end{array}$ & 3.81 & 3 \\
\hline $\begin{array}{l}\text { Newspaper in } \\
\text { Filipino }\end{array}$ & 3.30 & 5 \\
\hline $\begin{array}{l}\text { English Programs } \\
\text { in Radio }\end{array}$ & 2.94 & 6 \\
\hline $\begin{array}{l}\text { Newspaper in } \\
\text { English }\end{array}$ & 2.10 & 4 \\
\hline
\end{tabular}

The table indicates the media preferences of the respondents. The result says that respondents preferred to watch Filipino programs in TV however reading English Newspaper is the least priority. This entails that Filipino language remains strong in terms of media preferences. In general, respondents are uncomfortable with English language as to their preferences to media. In addition, Huang (2013) asserts that social medium has the potential to influence the exposure to English as a language in many countries. Thus, the amount of speech ability depends on the kind of media a certain learner of language preferred.

\section{Level of Speech Ability Of Grade 10 Students}

The succeeding tables present the oral language proficiency in terms of linguistic competence, discourse competence, pragmatics competence and fluency.

\section{Table 8}

\section{Respondents' Grammar Ability}

\begin{tabular}{|l|l|l|}
\hline Grammar & $\begin{array}{l}\text { Weighted } \\
\text { Mean }\end{array}$ & $\begin{array}{l}\text { Adjectival } \\
\text { Rating }\end{array}$ \\
\hline Orthography & 4.47 & Poor \\
\hline Semantic & 4.39 & Poor \\
\hline Morphology & 4.12 & Poor \\
\hline Syntax & 3.30 & Marginal \\
\hline $\begin{array}{l}\text { Total Weighted } \\
\text { Mean }\end{array}$ & $\mathbf{4 . 0 7}$ & Poor \\
\hline
\end{tabular}

The table indicates the grammatical ability of the respondents. Indicator "orthography" has a highest weighted mean of 4.47 or poor. The syntax has a weighted mean of 3.30 or marginal. Overall mean is 4.07 which mean the respondents' grammar ability is poor. Students with limited grammatical ability may be at increased risk of poor literacy.

Students often look on grammar teaching as a necessary evil at best. Many teachers are unwilling to teach grammar due to their own low skill level, students' low motivation and other reasons (Borg, 
2010) .Teacher's attitude towards grammar teaching and, correspondingly, assessment, depends very much on his/her own accuracy and fluency of grammatical skills, his or her self-confidence (Borg, 2001). On the other hand, grammar testing is a necessity, due not only to admission exams, school administration, etc. demand to hold it, but also to the necessity simply to know where you are and how well you can communicate (some grammar errors can make an utterance either vague or totally incomprehensible). Hence, it is concluded that grammatical ability gave contribution to students' speech ability.

\section{Table 9}

\section{Respondents' Vocabulary Ability}

\begin{tabular}{|l|l|l|}
\hline Indicators & $\begin{array}{l}\text { Weighted } \\
\text { Mean }\end{array}$ & $\begin{array}{l}\text { Adjectival } \\
\text { Rating }\end{array}$ \\
\hline Precision & 3.55 & Marginal \\
\hline Application & 4.01 & Poor \\
\hline $\begin{array}{l}\text { Total Weighted } \\
\text { Mean }\end{array}$ & $\mathbf{3 . 7 5}$ & Marginal \\
\hline
\end{tabular}

The table reveals that the respondents vocabulary ability is 3.75 or marginal. This means that there is no mastery of the principles vocabulary use. The marginal adjectival rating implies that respondents are unable to communicate functionally and interactively.

Vocabulary is an essential part of learning a language, without it, communication would suffer. A message could still be conveyed somewhat without a correct usage of grammatical structure, but without vocabulary, nothing is conveyed. Thus, one may expect a communication breakdown when the exact word or vocabulary itself is missing (Thornberry, 2002). Chastain as cited by Combed (2011)stressed that in the context of ESL teaching, it would make sense that the teaching of vocabulary should take priority over the teaching of grammar, especially in today's growing use of communicative approach where limited vocabulary is the primary cause of student's inability to express what to say in any speaking activities.

Table 10

Respondents' Pronunciation Ability

\begin{tabular}{|l|l|l|}
\hline Indicators & $\begin{array}{l}\text { Weighted } \\
\text { Mean }\end{array}$ & $\begin{array}{l}\text { Adjectival } \\
\text { Rating }\end{array}$ \\
\hline Enunciation & 4.02 & Poor \\
\hline Diction & 4.00 & Poor \\
\hline Total Weighted Mean & $\mathbf{4 . 0 1}$ & Poor \\
\hline
\end{tabular}

The table discusses the result of respondents' pronunciation ability. It can be seen in the table that the respondents' pronunciation ability obtains a weighted mean of 4.01 which means poor. This implies that respondents have a little difficulty in establishing the speech act with proper and exact pronunciation. The mispronounced words they send or receive lead not only to breakdown in communication, but also to bad effects within social relationships.

Pronunciation is a basic quality of language learning. Though most second language learners will never have the pronunciation of a native speaker, poor pronunciation can obscure communication and prevent an ESL student from making his meaning known In the past two decades, a number of studies have focused on English pronunciation teaching and it is evident that there is a growing interest in this field of research (Verne,2017).

Various attempts have been made to deal with relevant issues related to teaching practices, materials, training and attitudes to native speaker models both from the teachers' and the learners' perspective . Most of these studies have been conducted in ESL settings and in English-speaking countries such as Canada (Breitkreutz et al., 2001, Foote et al., 2011) Pronunciation assessment is yet another challenge that teachers are faced with in their professional lives. Despite the fact that pronunciation is a vital component of proficiency in spoken English, little published work seems to exist which addresses the issue of pronunciation testing and evaluation. This absence can be accounted for partly by the fact that "precise identification of pronunciation problems can be difficult even for experienced listeners" (Yates, Zielinski, \& Pryor, 2011, p.4).

\section{Table 11}

\section{Respondents' Fluency Ability}

\begin{tabular}{|l|l|l|}
\hline Indicators & $\begin{array}{l}\text { Weighted } \\
\text { Mean }\end{array}$ & $\begin{array}{l}\text { Adjectival } \\
\text { Rating }\end{array}$ \\
\hline Density & 4.06 & Poor \\
\hline Hesitation & 4.03 & Poor \\
\hline $\begin{array}{l}\text { Non-verbal } \\
\text { Comp. }\end{array}$ & 4.39 & Marginal \\
\hline Verbal Comp. & 4.01 & Poor \\
\hline Confidence & 3.45 & Marginal \\
\hline $\begin{array}{l}\text { Total Weighted } \\
\text { Mean }\end{array}$ & $\mathbf{4 . 0}$ & Poor \\
\hline
\end{tabular}


The table presents the respondents' fluency competence. It reveals that respondents gain a total weighted mean of 4.0 or poor. Such result connotes that the respondents are not fluent speakers at all .What does it mean to be fluent a speaker? Merriam Webster dictionary defines the word fluent for English language learner as able to speak the language easily, smoothly and very well. As studied by Tompkins (2011), fluency is important to student because once this stage is reached, students are reading and writing for comprehension and not decoding anymore.

In addition, in his study " English as a Second Language in Relation with Verbal Fluency in SBK Women University Quetta", problems of feeling inexpressive in target language are commonly expressed by majority of second language learners in learning to speak a second language. These problems are always considered to hinder the communication in the target language. As such, fluency can inhibit participation in classroom and extracurricular activities and affect peer relationships. Vocational/career choices may be limited, despite the individual's competency levels in non-speech areas.

\section{Part III. Significant Relationship}

This part of the analysis will provide the relationship between the Profile of the Respondents and the Level of Speech Ability using the Chi-Square Test.

\section{Table 12}

\section{Relationship of Language Facility to Speech Ability}

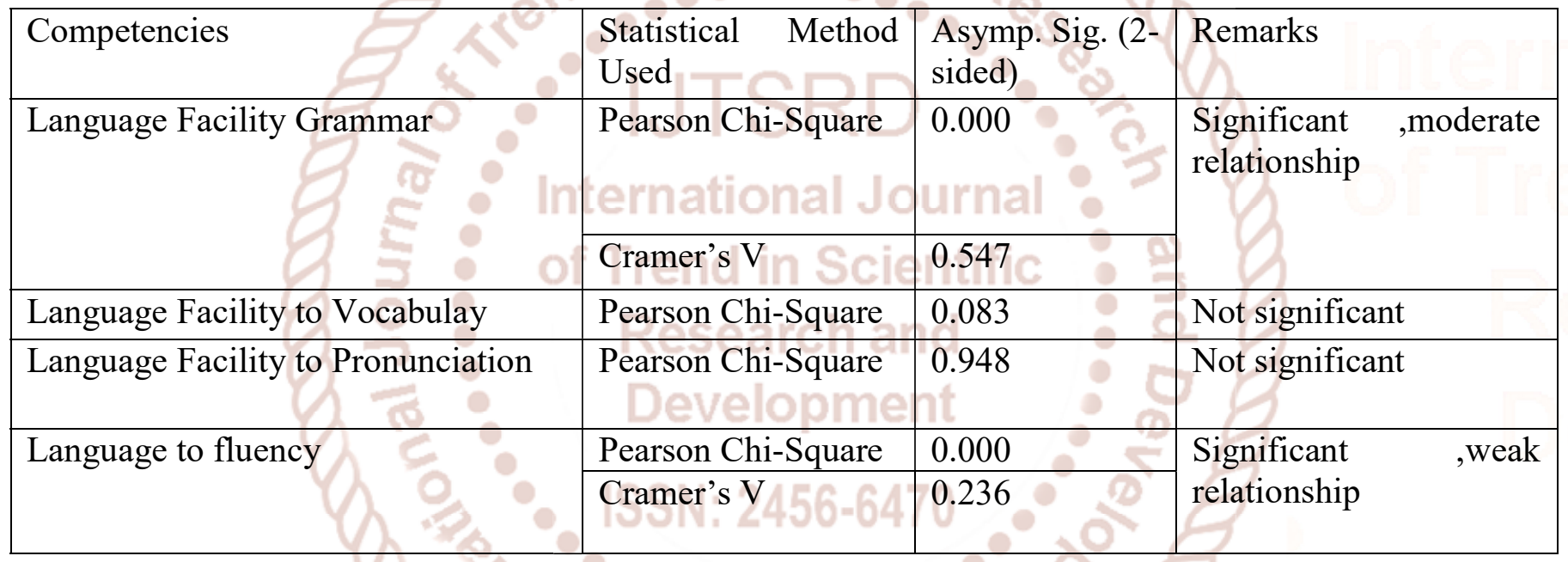

Table 12 shows the significant relationship between Language Facility and the speech ability .Both Grammar and fluency have computed values that are low(both have 0.000 Asymp. Sig. (2-sided)) thereby signifying that both have significant relationships but varies on the level of competency. On the other hands both pronunciation and fluency are not significant. This hints that the more the students use English in their daily undertakings in the classroom, the greater is the chance to improve their linguistic performance. 
International Journal of Trend in Scientific Research and Development (IJTSRD) ISSN: 2456-6470

Table 13

Relationship of Communication Practice to Speech Ability

\begin{tabular}{|c|c|c|c|c|}
\hline Competencies & $\begin{array}{l}\text { Statistical Method } \\
\text { Used }\end{array}$ & $\begin{array}{l}\text { Asymp. Sig. (2- } \\
\text { sided) }\end{array}$ & Remarks & \\
\hline \multirow[t]{2}{*}{ Use of English to Grammar } & Pearson Chi-Square & 0.000 & \multirow{2}{*}{$\begin{array}{l}\text { Significant } \\
\text { relationship }\end{array}$} & \multirow{2}{*}{,weak } \\
\hline & Cramer's V & 0.503 & & \\
\hline \multirow[t]{2}{*}{ Use of English to Vocabulary } & Pearson Chi-Square & 0.000 & \multirow[t]{2}{*}{$\begin{array}{l}\text { Significant, } \\
\text { relationship }\end{array}$} & \multirow[t]{2}{*}{ weak } \\
\hline & Cramer's V & 0.535 & & \\
\hline \multirow[t]{2}{*}{ Use of English to Pronunciation } & Pearson Chi-Square & 0.000 & \multirow[t]{2}{*}{$\begin{array}{l}\text { Significant, } \\
\text { relationship }\end{array}$} & \multirow[t]{2}{*}{ weak } \\
\hline & Cramer's V & 0.2000 & & \\
\hline \multirow[t]{2}{*}{ Use of English to fluency } & Pearson Chi-Square & 0.000 & \multirow{2}{*}{$\begin{array}{l}\text { Significant } \\
\text { relationship }\end{array}$} & \multirow[t]{2}{*}{,weak } \\
\hline & Cramer's V & 0.458 & & \\
\hline
\end{tabular}

The table shows that all competencies have a significant relationship as to the Communication Practice. As shown, the Pearson Chi-square assymp.sig.(2-sided) values are all less than the 0.05 standard level of significance, yet, Cramer's V values all signifies a weak relationship. That simply means that the Communication Practice has a small amount of influence to the fluency of Speech Ability.

\section{Table 14}

\section{Relationship of Use of English to Speech Ability}

The computed values as shown in the table display significant relationships between the dependent and independent variables, yet, among all competencies, it is the pragmatic competency that showed a strong relationship, as to the level of oral, language proficiency. This just simply means that using the language effectively to achieve a specific purpose greatly affects the student's level of speech ability.

Table 15

Relationship of Parent's Educational Attainment to Speech Ability

\begin{tabular}{|c|c|c|c|}
\hline Competencies & $\begin{array}{l}\text { Statistical Method } \\
\text { Used }\end{array}$ & $\begin{array}{l}\text { Asymp. Sig. (2- } \\
\text { sided) }\end{array}$ & Remarks \\
\hline \multirow{2}{*}{$\begin{array}{l}\text { Parent's Educational Attainment to } \\
\text { Grammar }\end{array}$} & Pearson Chi-Square & 0.000 & \multirow{2}{*}{$\begin{array}{l}\text { Significant, weak } \\
\text { relationship }\end{array}$} \\
\hline & Cramer's V & 0.480 & \\
\hline \multirow{2}{*}{$\begin{array}{l}\text { Parent's Educational Attainment to } \\
\text { Vocabulary }\end{array}$} & Pearson Chi-Square & 0.000 & \multirow{2}{*}{$\begin{array}{l}\text { Significant, weak } \\
\text { relationship }\end{array}$} \\
\hline & Cramer's V & 0.535 & \\
\hline \multirow{2}{*}{$\begin{array}{l}\text { Parent's Educational Attainment to } \\
\text { Pronunciation }\end{array}$} & Pearson Chi-Square & 0.000 & \multirow{2}{*}{$\begin{array}{l}\text { Significant, weak } \\
\text { relationship }\end{array}$} \\
\hline & Cramer's V & 0.358 & \\
\hline \multirow{2}{*}{$\begin{array}{l}\text { Parent's Educational Attainment to } \\
\text { fluency }\end{array}$} & Pearson Chi-Square & 0.000 & \multirow{2}{*}{$\begin{array}{l}\text { Significant, weak } \\
\text { relationship }\end{array}$} \\
\hline & Cramer's V & 0.258 & \\
\hline
\end{tabular}


Findings revealed in Table 15 that the parent's educational attainment has the P-value that is 0.00 less than 0.05 standard level of significance. The Cramer's V that measures the strength of relationship also shows that the parent's educational attainment has a significant relationship with the speech ability of the students. Parents are still effective partners of the language teachers and therefore one of the necessary stakeholders in their children's pursuit of ideal education.

\section{Table 16}

Relationship of Media Preference to Speech Ability

\begin{tabular}{|c|c|c|c|c|}
\hline Competencies & $\begin{array}{l}\text { Statistical Method } \\
\text { Used }\end{array}$ & $\begin{array}{l}\text { Asymp. Sig. (2- } \\
\text { sided) }\end{array}$ & Remarks & \\
\hline \multirow[t]{2}{*}{ Media Preference to Grammar } & Pearson Chi-Square & 0.000 & \multirow{2}{*}{$\begin{array}{l}\text { Significant } \\
\text { relationship }\end{array}$} & \multirow{2}{*}{,weak } \\
\hline & Cramer's V & 0.386 & & \\
\hline \multirow[t]{2}{*}{ Media Preference to Vocabulary } & Pearson Chi-Squ & 0.000 & \multirow{2}{*}{$\begin{array}{l}\text { Significant, } \\
\text { relationship }\end{array}$} & \multirow{2}{*}{ weak } \\
\hline & Cramer's V & 0.535 & & \\
\hline \multirow[t]{2}{*}{ Media Preference to Pronunciation } & Pearson Chi-Square & 0.000 & \multirow[t]{2}{*}{$\begin{array}{l}\text { Significant, } \\
\text { relationship }\end{array}$} & \multirow[t]{2}{*}{ moderate } \\
\hline & Cramer's V & 0.540 & & \\
\hline \multirow{2}{*}{ Media Preference to fluency } & Pearson Chi-Square & 0.000 & \multirow{2}{*}{$\begin{array}{l}\text { Significant } \\
\text { relationship }\end{array}$} & \multirow[t]{2}{*}{,weak } \\
\hline & Cramer's V & 0.483 & & \\
\hline
\end{tabular}

Taken as a whole, the media preference and the speech ability of the grade 10 students correlates each other. The computed P-value and the Cramer's V numerical figures display strength of relationship that varies from weak to moderate. This is an implication that media preference in terms of television, radio and newspaper still contributes to the development student's speech ability.

\section{SUMMARY, CONCLUSIONS AND RECOMMENDATIONS}

This chapter presents the findings, conclusions and recommendations of the study focused on the level of Speech Ability Grade 10 Students of Jose Sanvictores Sr. National School, S/Y 2016-2017.

\section{Findings}

The dominated gender among the respondents is male; the participants often use English in talking to teachers but sometimes express their opinion, explain their response, make request and give long answer to teachers' question; the respondents sometimes pronounce English words correctly and show adequate stock of vocabulary when speaking; the participants sometime use the English language in any communication; most of the respondents parents are high school graduates; respondents preferred to watch Filipino programs in TV and reading English Newspaper is the least priority.
The speech ability of the respondents is poor in the four components such as: grammar, vocabulary, pronunciation and fluency.

Further, there is a significant relationship between the profile of the participants and the level of speech ability.

\section{Conclusions}

After the data collection and interpretation, the following conclusions were drawn:

Boys are more active and than girls especially when a teacher calls for a certain activity to be done. Another thing is that boys like activities that involve psychomotor skills. They prefer action (like reading orally) rather than by just sitting down. Seldom use of the English language lets students wander too far in perfecting the language orally. Also, parents with low 
level of educational attainment do not help much in the development of the learners speech ability.

Also, poor speech ability of students affects their holistic development.

A significant relationship between the dependent and independent variable signifies that the relationship between the profile of the respondents and their speech ability is absolutely correlated. There is no doubt that their immersion and sufficient exposure to the English language in various ways greatly affects their level of speech ability. So the higher the chance in exposing them to English language, the higher is the possibility for them to do any communication tasks.

\section{Recommendations}

Based on the major findings of the study, and the conclusions drawn from those, there are some recommendations put forward to the English, teachers, the students, the parents and other researchers.

It is recommended that students should be given full attention so as to nail down their interest and males must be paired with females in all activities so as to lift up their being more left hemisphere and enthusiasm. Parents also may ask the teachers for some resources they can use at home. As to parents whose educational attainment is above average and below average, they can side by side learn the English language with their children through videos, books, newspapers and music. That would be very fun and exciting.

It is also recommended that students should change their attitude towards learning speaking the English language. They should be more confident and braver to speak English rather that feeling afraid of committing mistakes and be humiliated by their friends. They should not focus and worry too much on the grammatical accuracy which could prevent them from practicing English. They should, at least accumulate new word every day and use it to widen their vocabulary skills. Students should realize that mastering sufficient vocabularies is greatly important in the speaking skill. Without sufficient vocabulary mastery, they could not speak fluently.

It is further recommended that there is a need for the administrators, parents and teachers to devote time in harnessing the grammar, pronunciation, vocabulary and along with fluency. The teachers, therefore, together with the administrators and supported by the parents, are challenged to develop various teaching techniques. The variety of teaching techniques will help learners to get higher motivation to learn English especially speaking.

It is highly recommended that an intervention shall be done to address the problem on speech ability. A fast Friday project has been formulated to enhance their speech ability.

\section{REFERENCES}

1) Abihay J. Global English: "Philippines: World's best country in Business English. Business English Index (BEU).Vol.23. September 2014.

2) Arizona State Department of Education (1977). Task force findings specifying remedies available for eliminating past educational practices ruled unlawful under Lau versus. Nichols. (ERIC Document Reproduction Service No. ED346082).

3) August Oradee (2012). Improving schooling for language-minority children: a research agenda. Washington, D.C.: National Academy of Sciences, National Research Council, Board on Children, Youth and Families.

4) Bachman, L.F. (1990) Fundamental considerations in language testing. New York: Oxford University Press.

5) Bareket, B., \& Mohammadi, S. (2014). The contribution of the Teachers ${ }^{\text {ee }}$ Use of Dialogic Discourse pattern to the improvement of the Students $^{\text {ee }}$ Speaking Ability. Procedia - Social and Behavioral Science, 98, 353-362. doi: 10.1016/j.sbspro.2014.03.426.

6) Bailey, K. (2005).Practical English language teaching: speaking.New York:Mc Grew-Hill.

7) Borg, S. (2001). Self perception and practice in teaching grammar. ELT Journal, 52 (4), p. 273281

8) Borg, S. (2010). Contemporary themes in language teaching education. Foreign Languages in China, 7 (4), p. 84-89

9) Breitkreutz, J. A., Derwing, T. M. \& Rossiter, M. J. (2001). Pronunciation teaching practices in Canada. TESL Canada Journal, 19 (1), 51-61. 
10) Cabigon, N.H.D.,Steinel,M.P.(2013). Linguistic Skills and Speaking Fluency in Second Language Applied Pscholinguisitcs.

11) Chard V., and Thomas, W.P. (2006). Acquisition of cognitive academic language Proficiency: A six-year study. Paper presented at the Annual meeting of American Educational Research Association, New Orleans, LA.

12) Chavez , J. Cummins. Language Proficiency, Bilingualism and Academic Achieve, White Plains, NY: Longman. 2001

13) Coombie, C. (2011).Assessing Vocabulary in the classroom. retrieved March 11 from http//marifa.hct.ae./files/2011/07 vocabulary-in-the-language-classroom

14) Crandali, K.M. (2009). Learning about language assessment: dilemmas, decisions, and direction. Pacific Grove, CA: Heinlet \& Heinle Publishers.

15) Cummins, M. (1980). Theoretical bases of communicative approaches to second Language teaching and testing, Applied Linguistics.

16) Desales ,P.A. (2002). Coniderations in developing or using second language proficiency Adaptive tests.Language Learning \& Techology.

17) Disaling, M (2009). Speaking.Oxford: Oxford University Press

18) Duncan, K.(2005). A study on the learning process of English by higher secondary Students with special reference to dharamapuri district. Language in India .

19) Foote, J. A., Holtby, A. K. \& Derwing, T. M. (2011). Survey of the teaching of pronunciation in adult ESL programs in Canada. TESL Canada Journal, 29 (1), 1-22.

20) Hart , J. (2011)" The teaching and learning of French as a second language in two Distinct learning settings. Project report". Toronto: Modern Language Center, Ontarion Institute for Studies in Education

21) Hassan, $T$ (2012). What really matters in second language learning for academic Achievement. TESOL Quarterly Huang 2013

22) Hymes, D.H. (1972a) 'Editorial Introduction to "Language in Society"', Language in So-Ciety, 1.

23) Johnson, W., \& Packer, A. (1987). Workforce 2000: Work and Workers for the $21^{\text {st }}$ Century. Indianapolis, IN: Hudson Institute.
24) Jonsson, Paulston, C. B. and Tucker, G. R. (2010) Sociolinguistics: The Essential Readings. Malden, MA:Blackwell.

25) Lasala, Y ( 2014). A review of the impact of bilingualism on the development of pho-Nemic awareness skills in children with typical speech development. Child With typical speech development.

26) Lubin, S. (2000). Accuracy, Appropriateness, Improvement, Deepening: Approach To the Compilation of A New English Courses. Foreign Language World.

27) Lucas, S. ( 2001$)$.The arts of public speaking.( $7^{\text {th }}$ ed).Singapore:Mc- Graw-Hill.

28) Marzano,,Y.( 2005).On Developing of Pragmatic Competence and Improvement of Oral English Proficiency, Computer-Assisted Foregn Language Education.

29) Mohamed, M. (2002). “Language proficiency and Mental ability as related to critical: Thinking and academic achievement of secondary students: A casual modelling Study,"M.S. Thesis, Philippine Normal University

30) Moradi, Z., \& Talebi, S. (2014). The Effect of Pre-speaking Strategies Instruction in Strategic planning on Iranian EFL studentse Awareness as well as Students ${ }^{e e}$ Fluency and Lexical Resources in Speaking. Procedia - Social and Behavioral Science, 98, 1224-1231. doi: 10.1016/j.sbspro.2014.03.537.

31) Morozova, Y.(2013) Methods of Enhancing Speaking Skills of Elementary Level Students. Institute of Fundamental Education, Ural Federal University B. N. Neltsin Yekaterinburg, Russia.

32) Mosha, L.( 2014). "Correlated of English performance among fourth year high school Students in Philippine Science High SchoolEastern Visayas Campus, Science And Technology streams, “M.S. thesis, Leyte Normal University, Tacloban City

33) Osborn S., Osborn M., Osborn R. ( 2008 ).Public Speaking Guide Book. Boston. Pearson.

34) Patil ,Z. ( 2008 ).Rethinking the objectives of teaching English in Asia. Asian EFL journal.10(4),227-240.retrieved from http//www.asian-efjournal/december_08_2000.php 
International Journal of Trend in Scientific Research and Development (IJTSRD) ISSN: 2456-6470

35) Salvaleon, Rolly G.. Communicative Competence of HRM Students. Surigao del Sur State University. March 2009

36) Sato, Aina,"Students" Proficiency in English language relationship with academic Performance in Science and technical education," American Journal of Educational Research, vol.9.2000

37) Sholihin,U/www.zakynedia.com/2013/06definitio n-of-speaking.html.june 2013

38) Short, J. (2001) 'Semantic systems, discourse structures, and the ecology of language', In R.W, Studies in language variation. Washington, DC: Georgetown University Press. Pp.283.

39) Shumin,K. (1997)Factors to consider.Developing adult EFL students speaking abilities. English Teaching Forum.35(3),8.retrived from http://eca.state.gov./forum/vols/vol135/no3/p8htm

40) Suelto,S. (2015). The integration of linguistic competence into communicative compe Competence. Linguistic into Communicative Performance.

41) Tam,M.( 1997). Factors to consider: Developing adult EFL students speaking abilities. English teaching forum,35 (3) h8.retrieved from $\mathrm{http}: / /$ eca.state.gov/forum/vols/vol35/no1/p26.htm 1

42) Tokoz-Goktep, F. (2014). Speaking problems of 9th Grade High School Turkish Learner's of L2 English and Possible Reasons for those Problems: Exploring the Teachers and Students ${ }^{\text {ee }}$ Perspectives. Procedia - Social and Behavioral Science. 116, 1875-1879. doi: 10.1016/j.sbspro.2014.01.487.

43) Thornberry,S. (2002). How to teach vocabulary.Essex.Pearson ESL

44) Troike, W. (2004). Workforce: Work and workers for the $21^{\text {st }}$ century

45) Verne, Susan/busy teacher.org/4836-hoe-toevaluate-spelling.htm

46) Ward, S. ( 2017). http://www. The balance.com/speech-skills-and-technolog

47) Willmington, T (2001). A linguistic analysis of some English proficiency tests. TESOL

48) Yates, L., Zielinski, B. \& Pryor, E. (2011). The assessment of pronunciation and the new IELTS Pronunciation scale. IELTS Research Reports, 2,
1-46. [published online] Retrieved from: http://www.ielts.org/pdf/Vol12_Report1.pdf

49) Zaremba,AJ.( 2006).Speaking personality.Canada: Thompson South-Western. 